\title{
ORIGEN, PLATO AND THE AFTERLIFE
}

In the last twenty years there has been more debate than in the last two hundred as to whether Origen regards embodiment as a permanent or a temporary condition of human souls. Few specialists would now rely explicitly on the charge of his ancient critics that he held every embodied being to be by nature a naked intellect, which has fallen from the presence of God through negligence or repletion (koros), ${ }^{1}$ acquiring the status of angel, soul or demon in proportion to its demerits. ${ }^{2}$ Passages in the extant works of Origen that were thought to corroborate this charge are now perceived to admit of other readings. ${ }^{3}$ Some scholars now invite us to discriminate between a descent and a fall, ${ }^{4}$ between a first and a second fall, between voluntary and involuntary captivity, ${ }^{5}$ between rational agents (logikoi) on earth and rational entities $(\operatorname{logika})$ in the eternal mind of God. ${ }^{6}$ Those who profess to uphold a "traditional" view will often be found to have discarded or modified many assertions made by ancient witnesses; and while it has been customary to assume that the most traditional view is the most Platonic, some of those who wish to revise it have, knowingly or unknowingly, arrived at positions equally consistent with some form of Platonism.

It is also disputed whether all souls, in Origen's view, have already lived in paradise, and whether, if so, it was their first or their second habitation. ${ }^{7}$ In either case, an incorporeal paradise would entail that our embodiment is a temporary, and probably an unnatural, condition. This paper examines one passage in the First Principles which has always been perceived to have a bearing on the question of Origen's Platonism, but not so often to be an important key to his eschatology. I shall argue that the incorporeal realm of ideas which Origen rejects is the world to which our souls depart from the present life. In agreement with other scholars, ${ }^{8}$ I shall also assume that the realm of the departed is the paradise in which Adam and Eve are said to have been created, whether the biblical account of this is

\footnotetext{
${ }^{1}$ The classic study of this term in Origen is Harl $1985 .$.

${ }^{2}$ Origen: De Principiis, 96 Koetschau (Fr. 15 Koetschau) cited (as Origen) by, e.g. Kelly 2000: 180. On modern misuse of Koetschau's edition see Rombs 2007 and Behr 2017: xxvi-xxvii, with the comments of Crouzel and Simonetti 1978: 114-115. His Greek is not juxtaposed with the Latin of De Principiis 1.1.8 in Fernandez 2015: 308 or Behr 2017: 132.

${ }^{3}$ Thus First Principles 1.3.8-1.4.1 is taken to describe the fall of the soul into the body by Alviar 1993: $134 \mathrm{n}$. 30; Lampert 1996: 657; Dively Lauro 2004: 100-101; Heine 2010: 240n.; Humphries 2017: 15. Contrast Edwards 2002: 92-93, Behr 2017: xxxvi-xxxvii and Martens 2015: 614 n. 73, though Martens professes ignorance of the scholars cited in the previous sentence.

${ }^{4}$ Ramelli 2018: 255-263.

${ }^{5}$ Edwards 2002: 91-92.

${ }^{6}$ Tzamalikos 2006: 45 observes that the Greek is logika, not logikoi. Cf. Ramelli 2013: 173-180.

${ }^{7}$ For bibliography see Martens 2012: 216-220.

${ }^{8}$ See e.g. Martens 2019: 195-199; Blosser 2012: 244, citing Homilies on 1Kings 28.10.
} 
understood as history or as fable. Having shown that the description of this world which his opponents give is mirrored in Platonic commentaries on the myth of the afterlife in the Phaedo, I shall go on to meet three possible objections, namely that Origen might not have been acquainted with such commentaries, that he himself denied the corporeality of paradise, and that he would have had no reason in the First Principles, a work addressed to Christians, to enter a controversy that even philosophers found abstruse. In my concluding remarks I shall say what I hope to have contributed in this study to the academic debate that I have summarised in the opening paragraph.

\section{A Habitation for Souls and Ideas}

In a celebrated passage of his First Principles, Origen asks what the believer is to make of Christ's asseveration (John17.6) that neither he not his saints are of this world:

Cuius mundi difficilem nobis esse expositionem idcirco praediximus, ne forte aliquibus praebeatur occasio illius intelligentiae, qua putent nos imagines quasdam, quas Graeci i $\delta \varepsilon \dot{\alpha} \alpha$ nominant, adfirmare; quod utique a nostris rationibus alienum est, mundum incorporeum dicere, in sola mentis fantasia vel cogitationum lubrico consistenetm; et quomodo vel salvatorem inde esse vel sanctos quosque illuc ituros poterunt adfirmare, non video.(First Principles 2.3.6, 121.26-122.6 Koetschau).

Our reason for saying above that it was difficult to give an account of this world was the possibility of lending some people a pretext for their suspicion that we are affirming the existence of certain iconic forms ${ }^{9}$ to which Greeks give the name "ideas". In fact it is wholly foreign to our way of reasoning to speak of an incorporeal world, consisting only in the mind's imagination or in the vagaries of thought. And how they can affirm that the Saviour is from that place, or that each of the saints will go there, I do not see.

It is widely assumed that in this passage Origen is taking a side on the question as to whether the ideas (that is, transcendent archetypes of the phenomenal in Platonic thought) exist independently of the mind of God. In Plato's own Timaeus the realm of being is represented by a paradigm, apparently distinct from the Demiurge or creative Intellect, which contains the eternal models of all the natural kinds that populate the realm of mere becoming. It is not clear whether the Demiurge is the servant or the author of the paradigm and which, if either, corresponds to the Good which is at once the ground and the summit of existence in the Republic or to the One which precedes, yet perhaps contains, multiplicity in the Parmenides and the Philebus. The hypothesis that the paradigm exists in the mind of God was first propounded (so far as we know) by Philo of Alexandria, for whom no other solution was conceivable since his biblical theology could accommodate nothing superior to God or

\footnotetext{
${ }^{9}$ With Crouzel and Simonetti 1978: 150 and Wolfson 1956: 270, I assume the Greek original of imagines to be eikones.
} 
independent of his will. ${ }^{10}$ The first Gentile proponents of the doctrine that the ideas are thoughts of God are generally held to be Atticus ${ }^{11}$ and Alcinous, ${ }^{12}$ though the testimony of Eusebius regarding Atticus is challenged (as we shall see) by other witnesses, while the dating of Alcinous to the second century is not secure. ${ }^{13}$

Be that as it may, we do not doubt either that Origen had read Philo or that his acquaintance with the heterogeneous body of speculations that we loosely describe as middle Platonism was broader than ours. Nor is there any strong reason to contest the authenticity of a passage in modern editions of his First Principles, extant both in Greek and in Latin, which surmises that all genera and species, and "even those which are several in number" (i.e. particulars) have existed for ever in the mind of God (1.4.5). Hence, it is argued, the text reproduced above cannot be intended to gainsay the Platonic theory of ideas in all its variants, but only in that which makes the ideas external to the divine intellect ${ }^{14}$ - the position which, as we know, was maintained by Longinus against Plotinus, ${ }^{15}$ whom the majority of scholars believe to have been a fellow-pupil of Origen under Ammonius Saccas. ${ }^{16}$ This interpretation is harmonious with the known opinions of Origen ${ }^{17}$ and with his intellectual antecedents; for all that it does not explain everything in the present passage. For one thing, he does not attribute any other theory of ideas to the Greeks than the one that he repudiates here, and does not say at First Principles 1.4.5 that the contents of the divine mind are ideas. ${ }^{18}$ For another, he does not say at First Principles 2.3.6 that his interlocutors make the ideas independent of every mind but that they locate them in a realm that has no reality except in mentis phantasia. This locution, implying as it does that they exist in some mind but not in the demiurgic intellect, would be equally foreign to Platonists of both parties, to those who held the ideas to be self-subsistent no less than to those who defined them as thoughts of God.

\footnotetext{
${ }^{10} \mathrm{Cf}$., however, Republic 597b-c on the primordial bed.

${ }^{11}$ Dillon 1996: 254, citing Eusebius, Preparation for the Gospel 15.13, but also Proclus, Commentary on the Timaeus, vol. 1, 431.14ff Diehl, with 1, 305.6ff on the superiority of the demiurge to the paradigm. C. Moreschini, "Attico", in W. Haase and H. Temporini (eds), Aufstieg und Niedergang der römischen Welt II.36.2 (Berlin: De Gruyter 1987), 477-491 maintains that this tenet sets Atticus apart from the dominant tendency among Platonists of his time to regard the ideas as thoughts of God.

${ }^{12}$ Didascalicus 9.2. On Philo and Alcinous see Dillon 2011.

${ }^{13}$ The identification with Albinus was cogently challenged by Whittaker 1987.

${ }^{14}$ See Crouzel 1961: 54; C. O’Brien: 255; Tolan: 135-136

${ }^{15}$ See Porphyry, Life of Plotinus 18.10-19 and 20.89, with Armstrong 1960.

${ }^{16}$.On Ammonius as a common source for Plotinus and Origen see D. O’ Brien 1992.

${ }^{17}$ Ramelli 2017: 24-25 demonstrates that he held what we would call a variant of the theory of ideas.

${ }^{18}$ Cf. Tzamalikos 2006: 48.
} 
One expedient might be to treat the words in mentis phantasia as Origen's own parenthesis, satirically implying that this world of ideas has no existence outside the fancy of heretics. This would appear to be the view of Crouzel and Simonetti; ${ }^{19}$ syntactically, however, these words belong to the same construction as the words mundum incorporeum, and would therefore seem to be equally intrinsic to the position fathered on Origen's opponents in oratio obliqua. We might propose instead that his opponents had anticipated Plotinus by assigning the ideas to the demiurgic intellect but placing the latter below the First Principle. Plotinus was, however, an innovator who had yet to commence his studies when Origen wrote First Principles. Had Origen already heard a similar teaching in the seminars of Ammonius, he would not have disowned it with such unfilial levity, and in any case we cannot suppose that Ammonius was any more willing than Plotinus to admit phantasia to the noetic realm. Atticus might be more plausibly suggested as Origen's adversary if we follow a report in Syrianus which hints that for him the seat of the ideas was not the demiurgic intellect but the world-soul. ${ }^{20}$ Syrianus, however, contradicts an excerpt made from Atticus by Eusebius, in which the ideas are said to be thoughts (noêmata) of the Demiurge, ${ }^{21}$ and we have no evidence from any source that Atticus thought of the ideal realm as either the first or the future abode of souls.

I propose then that we look for light in another controversy that divided the philosophers of this era, one that was not expressly concerned with the status of transcendent forms or ideas, but with the role of phantasia in shaping the soul's environment after its separation from the gross body. I shall not consider whether the adjective Platonist is applicable to Origen in any other sense than that his reading of Plato sometimes furnished the means of removing an obstacle to his efforts to build a philosophy from scripture. No scholar denies that Greek philosophy had at least a catalytic effect on Christian reasoning, so that debates on the possibility of eternal generation within the Godhead mirrored those which taken place with respect to the use of the terms gennêtos and genêtos within the Timaeus, ${ }^{22}$ and different species of mixture, as delineated by Stoics or Platonists, furnished competing models for the union of divine and human properties in the Saviour. ${ }^{23}$ Platonism, being the one philosophy that concurred with Christianity in proclaiming rewards and punishments for every soul in the

\footnotetext{
${ }^{19}$ Crouzel and Simonetti: 150 suspect an ironic echo of the Stoics.

${ }^{20}$ Commentary on the Metaphysics, p. 35 Kroll, cited by Dillon 1996: 256.

${ }^{21}$ Preparation for the Gospel 15.13, p. 815a = Atticus Fr. 9 Des Places.

${ }^{22}$ Stead 1964.

${ }^{23}$ Briggman 2019: 139-180.
} 
afterlife, provided the church with a mine of speculations, none of which could be subsumed without change into a faith that proclaimed the resurrection of bodies rather than the immortality of souls.

\section{Platonic itineraries of the soul}

In Plato myth is the vessel for every account of the trials and peregrinations of the soul. In the second of Socrates' speeches in the Phaedrus we are informed that the soul is naturally immortal, being the only possible origin of its own motion, $(245 \mathrm{c})$ and that its natural motion is to follow its god in the train of Zeus in the hope of sharing the vision of justice, wisdom and knowledge in the supercelestial heaven (246a-247a). It is here that Truth appears to the soul in its plenitude, with none of the sensory trappings that disguise it from us in the phenomenal world (247c-d). The soul's success in this quest depends on the skill and energy of its rational element, which is depicted as the driver of a winged chariot (247a); the horses who draw the chariot stand respectively for our spirited and appetitive propensities; if the driver fails to restrain its natural incontinence, the appetitive horse will cause the team to crash $(247 b ; 248 b)$, the wings will be broken, and the soul will commence a life in the lower world which corresponds to the gravity of its transgression (248c-e). The soul that falls least far from the truth is that of the philosopher $(248 \mathrm{~d} ; 249 \mathrm{c})$, and when its recollection is stirred by the sight of beauty on earth (249c-d), it will devote itself to the cultivation of an answering beauty in the soul of the pupil (250a-c), always taking care to prevent the incontinent horse from kicking over the traces once again in its craving for carnal intercourse (253e-254a).

Although it is often asserted that the supercelestial heaven is the realm of forms, ${ }^{24}$ the word idea is absent from this dialogue, ${ }^{25}$ and only at $249 \mathrm{~b}$-c does Socrates intimate that we must apprehend truth as an eidos. We also look in vain for the presiding form of the Good, unless it is silently equated with truth or being. The narrative does not follow the soul's ascent after quitting the body in this world, and we never learn whether the chariot is a decorative figment or a symbolic representation of some vehicle which is required to sustain the soul and its divine pilot even in the highest sphere. ${ }^{26}$ Such questions exercised the Neoplatonic commentators of late antiquity, and Proclus concludes (in partial opposition to Plotinus) that the rational soul accompanies the lower soul in its fall and return, that neither the irrational nor the rational soul will cease to inhabit a vehicle of some sort when they are freed from

\footnotetext{
${ }^{24}$ See e.g. Lear 1989.

${ }^{25}$ In the account of collection and division at $277 \mathrm{~b}$ the idea is the genus of which the eidos is the species.

${ }^{26}$ See Dodds 1963: 313-321; Finamore 1985: 1-6.
} 
mundane embodiment, and that the gods whom the soul pursues belong to a lower tier of existence than the noetic. ${ }^{27}$ The silence of Plotinus, ${ }^{28}$ however, suggests that there had been little discussion of these problems in the second century, when it seems that the Platonic myths which commanded most attention were those that cast the gods in their more quotidian role as judges assigning another life in the present world to unemancipated souls.

The dialogues in which these myths are most fully elaborated ${ }^{29}$ are the Gorgias and the Phaedo, the former of which predicts, while the latter narrates, the death of Socrates himself. In the Gorgias he relates that at first, when mortals were judged by mortals in the present life, the great wrongdoers came before their peers in all their intimidating splendour and were frequently acquitted (523b-d). Zeus therefore ordained that they be judged after death when the soul was stripped of all externals, so that just as the corpse retains the traits and scars of the living body, so the soul would exhibit all the stains and deformities that had accrued to it from its sinful acts $(523 \mathrm{e}-525 \mathrm{c})$ The consequence is that tyrants who were flattered and revered in their days on earth now expiate their sins in Tartarus, while philosophers whom the world pitied and spurned go at once to the Isles of the Blessed (525d-526d). In the commentary of Olympiodorus, a Platonist of the sixth century, we are warned that souls do not undergo locomotion and that their nakedness betokens the exposure of the conscience to divine scrutiny (Commentary on Plato's Gorgias, 48.3, pp. 251-252 Westerink). While Plato speaks in the manner of the geographers, he means by the place of judgment the border between the realms of becoming and being (49.3, p. 259); by judgment below the earth he means the extinction of evil passions, and by the Isles of the Blessed the noblest and happiest condition of the soul (47.6, pp. 246-247). For all that, no doubt is raised as to the literal existence of the soul after death or of the gods who judge it, and Olympiodorus does not deny that the soul may undergo a moral purgation as it rises through the planetary spheres (see esp. 50.3 , p. 263).

\section{The Phaedo and its afterlife}

The afterworld of the Phaedo is neither a place below our earth nor an unapproachably distant one. The earth as we know it, says Socrates, is a sediment in the hollows of a much greater expanse (109c), whose upper regions charm their denizens with stones more lustrous, plants more lovely and colours more brilliant than any that have yet been revealed to our

\footnotetext{
${ }^{27}$ Commentary on Timaeus, vol. 3.234.8-238.3 Diehl; see Timaeus 41b-c.

${ }^{28}$ See Schibli 1993: 110, although he also proposes middle Platonic antecedents.

${ }^{29}$ See also Republic 615a-621b and Timaeus 90a-92c, the second of which contains some facetious elements.
} 
benighted senses $(110 \mathrm{c}-\mathrm{d}) .{ }^{30}$ This greater world is enclosed and penetrated by four rivers, Acheron, Styx, Pyriphlegethon and Cocytus. Every soul that quits the body must pass through the chasm of Tartarus (112a) and learn its destination from its judges. The obdurately wicked remain in Tartarus (113e), the philosopher is translated to the place of bliss, the souls that have done little evil or good are purified in the Acherusian lake (113d), and those who are guilty of graver but remediable sins are immersed in either Cocytus or Phlegethon (114a).

The commentary of Damascius on the Phaedo differs in two respects from that of Olympiodorus on the Gorgias: he does not reject the geographical reading and he cites the opinions of his predecessors even where they are not his own. From the following passage, therefore, we learn not only what opinions might be held but which were already held in the time of Origen:

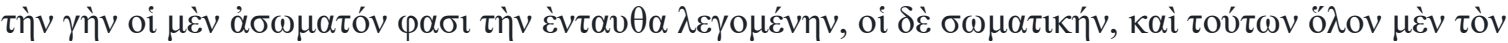

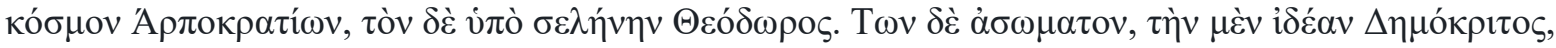

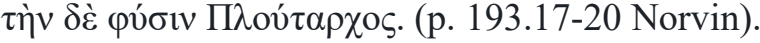

Some say that the earth which is said to be 'here' (Phaedo 108c) is incorporeal, some that it is corporeal. Of the latter Harpocration takes it to mean the whole cosmos, Theodorus that which is under the moon. Of those who take it to be incorporeal, Democritus takes it to mean the idea, Plutarch the nature.

Plutarch offers numerous variations on the myth of the Phaedo, in which it is often difficult to winnow the literal from the symbolic even when we are certain that the speaker is neither amusing himself nor an object of amusement to the author. Some of his speakers at least believe that traces of corporeality cling to the irrational soul so long as it is not purged of its carnal passions, and that even the liberated soul retains a luminous body. Thus, in The Face in the Moon (30) we are told that all souls after death must enter the space between the earth and the moon, and that who are most encumbered by vice will sink to the abyss of Tartarus while the most virtuous will ascend to the moon itself. Democritus the Platonist is an undistinguished figure by comparison, but undoubtedly a contemporary of Origen, since he is mentioned by the polymath Longinus among the philosophers whose lectures he has attended. ${ }^{31}$ Damascius himself disagrees with both:

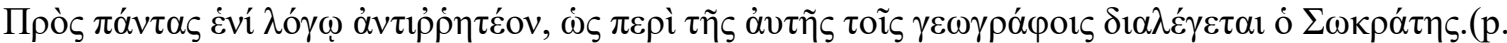
193.21-22 Norvin)

Against them all it must be said in one word that Socrates is speaking of the same world as the

\footnotetext{
${ }^{30}$ The true earth is said to be situated in heaven; on Origen's paradoxical topography of paradise see Rankin 2017: 111-126.

${ }^{31}$ Porphyry, Life of Plotinus 20
} 
geographers.

The scholion that follows is defective, but where the text becomes clear it suggests that Democritus held the idea to be the pre-eminent and indivisible bearer of a predicate which is never so fully instantiated in the phenomenal realm:

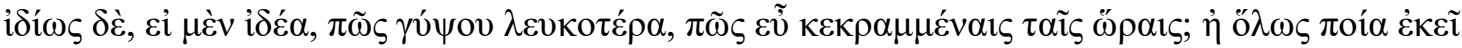

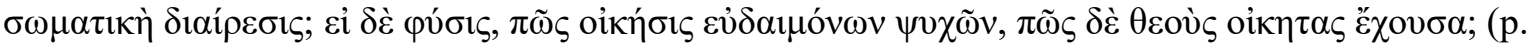
194.3-5 Norvin).

In particular, if that which is 'whiter than gypsum' (Phaedo 110c) is the idea, what is meant by 'the seasons being well blended' (111b)? In general, what division of bodies can there be there? And if it is nature, how can it be a habitation for happy souls or be inhabited by gods?

A little later, Damascius wonders what is the source of that pleasure in myths which Plato believes to be characteristically human:

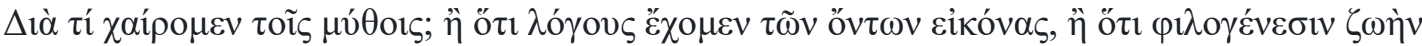

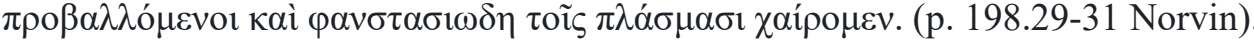

Why do we "take pleasure in myths" (Phaedo 110b)? Either because words are what we have as icons of reality, or because we prefer the life that cleaves to generation and sensory images and therefore take pleasure in fictions.

The eikastic and the phantastic are the two modes of mimetic art distinguished by the Eleatic Stranger in Plato's Sophist (235c-236c). The former imitates things in the world, while the latter devises figments which have no equivalent in reality. Plato, disdaining both, prefers the eikastic mode, which is the one that Damascus seems to attribute to him when he describes

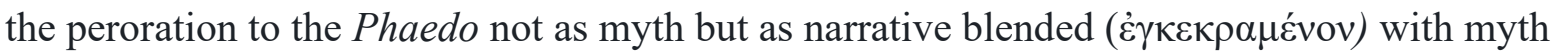
(p. 199.18 Norvin). By contrast, a commentator who held, with Democritus the Platonist, that the dialogue lays a map before our senses of realms that have no sensible form or geographical location would employ the term phantasia.

Democritus is contending, not that the afterlife itself is imaginary, but that Plato's representation of it is phantastic inasmuch as it drapes invisible realities in images derived from the sensible world. ${ }^{32}$ For him, as for other Platonists, phantasia is a pedagogic instrument which imparts to the captive soul a shadowy intimation of truths that it will grasp by pure intellection and without any sensuous intermediary once its rational element is

\footnotetext{
${ }^{32}$ See Iamblichus, Common Science of Mathematics, pp. 19-20 Festa.
} 
entirely released from commerce with the body. What would it mean to say, then, that the incorporeal realms of souls subsists in mentis phantasia alone? In Plotinus the word hypostasis tends to denote reality in an apprehensible mode as opposed to the absolute mode in which it is unknowable, at least while we remain in a given epistemic state. Thus, at Enneads 5.6.1, whatever being can be ascribed to the One is possessed by the soul (but not the One) in a hypostatic manner. ${ }^{33}$ When, therefore, a contemporary of Plotinus says that the incorporeal afterlife has its hypostasis only in fantasy, he means that the myth which has rendered it apprehensible is only a phantastic, not an iconic, representation of truths which Plato himself admits elsewhere to be inexpressible.

On this reading, therefore, Origen rejects the view that corporeal representations of the afterlife in scripture are merely phantastic. At the same time, he implicitly affirms the superiority of the eikastic to the phantastic in his own contrast between the icon and the idol in his Homilies on Exodus (8.3) $)^{34}$ - a passage which suffices to show that he grasped, as keenly as Plato, the distinction between a picture which merely falls short of reality and a picture of the unreal.

\section{Origen's knowledge of Platonism ${ }^{35}$}

It is likely enough that Origen derived his knowledge of Platonism chiefly from his intercourse with living representatives of the school. On the other hand, his quotations from the dialogues in the work Against Celsus are various enough, and sometimes recondite enough, to show that he was not dependent only on second-hand acquaintance or on a florilegium. Nevertheless, he appears to cite no more than a phrase from the Gorgias in this treatise, ${ }^{36}$ and one of his two allusions to the Phaedo tells us it is named after a young satellite of Socrates whom he rescued from a brothel (1.64). The other, however, testifies to his acquaintance both with the dialogue and with its commentators, for, in answering his adversary's charge that the author of Revelation filches the stones and trees of his New Jerusalem from this source (7.28), he retorts that Plato's fancy - which the best of his own

\footnotetext{
${ }^{33}$ Cf. Proclus, Ten Questions on Providence 1.7 on the hypostasis of knowledge within the knower, which takes its character from the thing known.

${ }^{34}$ See Damascius, In Phaedonem, p. 198.33 Norvin for objects of phantasia as eidêla.

${ }^{35}$ For general studies of Origen's knowledge of Plato see Dorival 1992; Limone 2018: 148-223.

${ }^{36}$ Against Celsus 6.37 echoes the definition of rhetoric as the "artificer (dêmiourgos) of persuasion at Gorgias 454a.
} 
disciples admit to be an allegory ${ }^{37}$ - is most probably derived from the same Isaiah who furnished the Christian visionary with his symbolism. ${ }^{38}$ If Plato speaks in ciphers, as Celsus says, this is no less true of the Christian scriptures: while the nature of the new Jerusalem cannot be fully divulged to profane inquirers, Origen is prepared to say that the land (gé) which it occupies is in the heavenly regions, not on this planetary earth $(6.25 ; 7.19)$.

Origen was sufficiently conversant with the Phaedrus to deride its account of the soul's ascent through the spheres as a plagiarism from Jacob's vision of a ladder from earth to heaven ${ }^{39}$ at Against Celsus 6.21. At Against Celsus 8.4 he assimilates the lesser gods and daemons of this dialogue to the angels and evil spirits of the New Testament. ${ }^{40}$ Both in his answer to Celsus and in First Principles he associates the return of the soul to God with Plato's adjective "supercelestial"; ${ }^{41}$ and if he held that the grossness of its transgression determines whether an intellect sinks to the state of an angel, a soul or a demon, an analogy could be drawn with Phaedrus 248c-e, where the soul's lot in the present world is commensurate with the gravity of its fall. Since, however, the evidence for his holding this position is not secure, ${ }^{42}$ it cannot be reckoned among the manifest proofs of his acquaintance with the Phaedrus. This being said, we could wish for no clearer proof than his assertion that the church has a story superior to Plato's conceit that the soul is pent on earth by the loss of its wings (Against Celsus 4.40). On the second occurrence of the word pterorruêsas, ${ }^{43}$ this proves to be an account of the fall of angels rather than the human soul.

In a much less eristic spirit, Origen occasionally quotes his older contemporary Numenius of Apamea as a witness to the authority of both the Septuagint and Christian testimony to the life of Jesus. Numenius is otherwise known to us chiefly as the author of a treatise On the Good, from which copious excerpts are transmitted by Eusebius, and of an allegory of the myth of Er in Plato's Republic, which, to judge by the citations in Porphyry's Cave of the Nymphs, must also have encompassed an allegorical reading of parts of the Odyssey. ${ }^{44}$

\footnotetext{
${ }^{37}$ We know too little of these "disciples" to estimate Origen's debt to them. Heine 1995 and Ramelli 2014 find a model for his commentaries in those of Alexander of Aphrodisias on Aristotle. For comparison with Neoplatonic commentators see Hadot 1987 and Bendinelli 1997.

${ }^{38}$ Against Celsus 7.30, citing Isaiah 54.12. At 7.28 Celsus quotes Phaedo 109b, locating Plato's afterworld in heaven.

${ }^{39}$ See Genesis 28.10-19; John 1.51.

${ }^{40}$ Citing Phaedrus 250b and 246e-247a, with 1 Corinthians 2.6 and 8 and 2 Corinthians 11.14.

${ }^{41}$ Against Celsus 6.19-20, once explicitly citing Phaedrus 247c; First Principles 2.3.6, 2.9.3. For possible reminiscences of the myth see also Against Celsus 1.17, 1.20, 3.63, 3.80, 4.17, 4.53, 5.20, 5.42, 7.44.

${ }^{42}$ See n. 2 above, with Martens 2015: 614, n. 73.

${ }^{43}$ Against Celsus 6.43, alluding to Plato, Phaedrus 248c-e. Pace Martens 2015: 619, the doctrine superior to Plato's, to which Origen alludes at 4.40, does not concern the pre-existence of human souls.

${ }^{44}$ Lamberton 1986: 54-77.
} 
Origen, who appears to be more familiar with the allegoresis than with the metaphysics of Numenius, ${ }^{45}$ will always have had an ear open for any possible corroboration of scripture in his exegesis. A passage which weaves the four rivers of the Phaedo into the topography of the myth of Er may therefore have suggested to him a parallel between the afterworld in Plato and the Biblical Eden. According to Damascius, Numenius was of the party that identified the afterworld with the ouranos or heaven, and held it to be in some sense corporeal; ${ }^{46}$ such a position would be consistent with his teaching (also attested by Damascius ${ }^{47}$ ) that what survives in the next life will be not only the nous or the soul but the empsukhon, the thing ensouled.

Origen knows of Greeks who posit not merely two but three transcendent principles whom they call gods (Against Celsus 5.7); in our present state of knowledge, this opinion can be attributed with more confidence to Harpocration than to his contemporary Numenius. ${ }^{48}$ Harpocration is also said by Damascius (above) to have construed the strange earth of the Phaedo as the ouranos. Thus Origen was acquainted with two Platonists who understood the intermediate realm of souls to be in some sense corporeal, in which case he can hardly have been ignorant that there were Platonists with whom they disagreed. It is not surprising that in his reply to Celsus he should favour those whose beliefs coincided with his own reading of Christian orthodoxy; nor is it surprising that in his First Principles he should refuse any view of the destiny of saints that was based upon the teaching of their adversaries.

\section{Did Origen Deny the Corporeality of Paradise?}

I have not so far considered any countervailing evidence that Origen himself maintained the incorporeality of paradise, and must therefore have been censuring some other Greek speculation at First Principles 2.3.6. The difficulty could be obviated by arguing that the paradise of the saints is not the same place as the garden of Eden, and that scholars have argued only for the incorporeality of the latter. The principal advocate of this thesis in modern time however, is Peter Martens, who also holds that the eschatological paradise and the protological paradise are one. ${ }^{49}$ He acknowledges that he is many other scholars have taken a different view in the light of texts which seem to acknowledge that sexual difference

\footnotetext{
${ }^{45}$ Against Celsus 1.5, 4.51, 5.57. Plutarch's (lost) On the Soul is cited at 5.57.

${ }^{46}$ Fr. 35.5-10 Des Places. For refinement of Proclus' evidence see Tarrant 2015: 141-143.

${ }^{47}$ In Phaedonem 124.13-18 Norvin = Numenius, Fr. 46a Des Places.

${ }^{48}$ Boys-Stones 2012.

${ }^{49}$ Martens 2019: 195-200.
} 
already existed in Eden, ${ }^{50}$ and an extract in a catena from his Commentary on Genesis, which notes that some have identified the coats of skin with embodiment and others with mortality, does not concur with either. ${ }^{51}$ Most attempts to harmonise the evidence postulate a change in the quality of Adam's body, rather than a shift from a perfectly incorporeal to a corporeal state. $^{52}$.

It will not be necessary to canvass any of these theories here, since all, whatever they understand the original condition of the soul to have been, attribute a body of some texture to Adam before the fall, and thus imply that his paradise was corporeal, if only in a sense homonymic with the everyday usage of that term. Only a demonstration that Origen held the paradise of Adam and Eve to be in the strict sense incorporeal would be fatal to my argument in this paper. I shall therefore turn my attention here to the passages which Martens adduces to show that Origen" could" have found support in Genesis 1-3 for his theory that souls originate in an incorporeal realm. ${ }^{53} \mathrm{He}$ appears to concede that Origen might also have countenanced 'literal' (by which he can only mean somatic) readings of these chapters; ${ }^{54}$ since, however, he states without qualification that Origen not only 'rejects a literal paradise' but believes the true paradise to be an incorporeal realm, ${ }^{55}$ it is hard to imagine a 'literal' exegesis which, on this view, would have been consistent with Origen's belief in the inerrancy of the scriptures. Martens himself does not admit that any of the texts which he cites from Origen leave open the possibility of an incorporeal paradise, and he is certainly right to construe the following passage as an a satirical critique of literalism: ${ }^{56}$

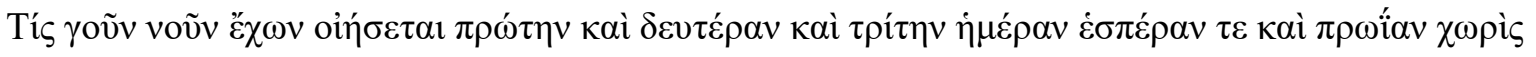

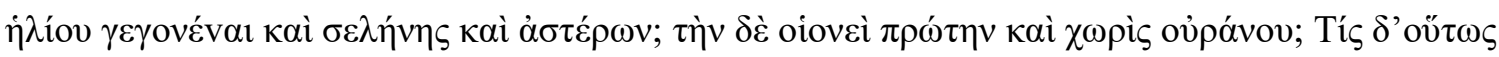

\footnotetext{
${ }^{50}$ On Against Celsus 7.39 see Edwards 2019: 177.

${ }^{51}$ Origen, Genesis Commentary, 190.24-192.2, Metzler, from Collectio Coisliana fr. 121.

52 Blosser 2012: 201 believes that the skins represent the transition from spiritual to gross embodiment. Pârvan 2012: 64 equates them with our fall to a position between death and life. For the argument (drawing, like that of Pârvan on Homilies on Leviticus 6.2) that they stand for a combination of mortality and corruption see Edwards 2019: 179-181. Clark 1992: 93-94 opines that Origen's ancient critics failed to distinguish the carnal from the spiritual body. Martens 2014: 76-77 contends that the skins were literally created by God to symbolise the mortality and fragility incurred by the fall (Homilies on Leviticus 3.6.7).

${ }^{53}$ For the term "incorporeal see Martens 2012: 516, 523, 525n, 529, 539n, 540.

${ }^{54}$ See especially Martens 2012: 520. In all the term "literal" occurs 15 times. At 536 he states that "Origen could interpret" the coats of skin "allegorically", with an emphasis on "could" that he reiterates in Martens 2019: 192. He says indeed "this is how I introduced my discussion", although Martens 2012 begins not at p.536 but at p.516.

${ }^{55}$ See especially Martens 2012: 539-540, “since paradise was an incorporeal realm” (my italics). Cf. 516: "drama of incorporeal rational minds". At 2019: 192 he prefers the formulations "divine and heavenly realm distinct from this earth" and "protological residence of pre-existent rational creatures" (from 2012: 536-537. ${ }^{56}$ Philokalia 1.17, quoted by Martens 2012: 522-523. The Latin appears at First Principles 4.3.1.
} 


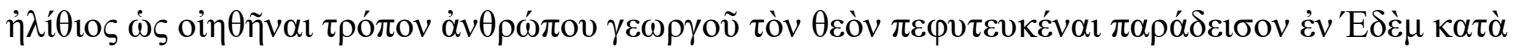

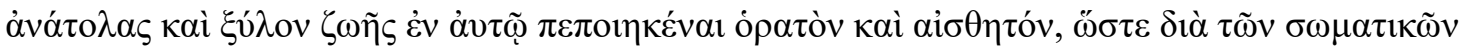

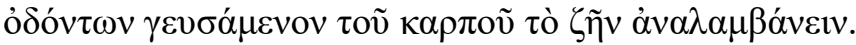

Who that has any intelligence at all will suppose that a first, a second and a third day, a morning and an evening, took place without a sun, a moon or stars? And the first day (so to speak) without even a heaven? Who was ever so witless as to suppose that God, in the manner of a human cultivator, planted a garden in Eden in the east (Genesis 2.8) and created in it a visible and perceptible tree of life (Genesis 2.9), so that one could obtain life by tasting the fruit with corporeal teeth?

Martens is right again to say, in response to Mark Edwards, ${ }^{57}$ that Origen is not rejecting merely the anthropomorphic interpretation of the verb "plant" as he rejects the anthropomorphic interpretation of God's "coming down" to overthrow the Tower of Babel. He is also denying that the trees of Eden were our own botanical specimens and that the fall was a simple act of mastication. But is he therefore denying any form of corporeality to Eden and its inhabitants? If his thought is informed by Platonism, he will have known that certain Platonists envisaged a state between earthly lives in which souls are neither domiciled in gross bodies nor wholly free of corporeal traits. We do not depend solely on inference, for in his own writings Origen attributes tenuous bodies to demons, bodies of light to angels and a posthumous vehicle to the human soul which preserves its capacity for motion. ${ }^{58}$ When he returns to Babel at Against Celsus 5.31-32, he intimates that even texts which we read as history may contain many tropes with a deeper meaning. Again, when he argues that the opening words of Jeremiah are more literally true of Christ than of the prophet, he is forced to grant that certain terms are metaphors even when applied to Christ as a figure of history. ${ }^{59}$ Neither these passages nor his frequent allusions to the mystery concealed in the story of Eden prove that Origen denied the corporeality of humans in their first or their final state. .

In the same article Martens discusses the coats of skin at Genesis $3.21,{ }^{60}$ on which I have commented above, and notes, as I have done, that some analogy between biblical narrative

\footnotetext{
${ }^{57}$ Martens 2019: 196, criticising Edwards 2019: 166-167. Martens 2014: 77 acknowledges that a reading might be called literal, yet exclude an anthropomorphic conception of God.

${ }^{58}$ First Principles, proem 10; Against Celsus 5.19; First Principles 1.6.4 with Ramelli 2018: 254..

${ }^{59}$ Origen, Jeremiashomilien, ed. E. Klostermann (Leipzig: Hinrichs 1901), 4-5.

${ }^{60}$ Martens 2012: 536-540, with a rather truncated paraphrase of Codex Coisliniana, fr. 121. He notes that Origen deems it pithanon ("persuasive") that the skins should represent bodies but ignores his qualification, "it is not clear if it is true". He claims the support of Simonetti 1962, but in fact this author denies that Homiliies on Leviticus 6.2, contains "un' allusione alla creazione dei corpi mortali di Adamo ed Eva come conseguenza del peccato" (pp. 373-374). Again he cites Bammel 1989: 72-73, but Bammel surmises that Origen identifies the skins with bodies of flesh and bone without denying to Adam a body of some kind before the fall.
} 
and Platonic myth is acknowledged by Origen himself. ${ }^{61}$ He also construes a number of texts from the Commentary on the Song of Songs as references to a pre-existent church; ${ }^{62}$ since, however, none of these equates the church with paradise or declares that the souls composing it were bodiless, the difficulties of translation and exegesis that these passages raise need not detain us here. To this evidence he adds three passages from Against Celsus, in which paradise is said to be not on this earth and the Biblical narrative is declared to be allegorical or to have philosophical import. ${ }^{63}$ These texts are, of course, deliberately elliptical, and Martens' identification of the allegorical with the incorporeal does not sit well with Paul's use of the term allêgoroumena at Galatians 4.24. ${ }^{64}$ This, the only occurrence of a word connoting allegory in the Bible, was not understood by Origen to mean that Hagar and Sarah were incorporeal beings. Origen's denial that paradise can be found on earth (Against Celsus 7.2829) may have some force against particular claims by Edwards, but it does not prove either the paradise of Adam or the paradise of the saints to be incorporeal, whether these be one place or two. Passages which imply that John the Baptist, Jacob or Jeremiah came from another world ${ }^{65}$ are designed to explain their extraordinary role in the scheme of providence, and therefore cannot be adduced as though they were typical of all humans; it is not for nothing that Origen entertained the speculation that the Baptist was an angel in human guise. $^{66}$

Martens has now compiled a second dossier which includes some texts which once again separate paradise from earth without questioning its corporeality, ${ }^{67}$ together with a battery of proofs to explode any doubt as to whether Origen maintained the pre-existence of the soul. ${ }^{68}$ Since Edwards has addressed the second group of texts elsewhere, ${ }^{69}$ and since they make no reference to paradise, I need not devote a further excursus to them in this study. Nor again

\footnotetext{
${ }^{61}$ Martens 2012: 540, citing Against Celsus 4.40, but not Against Celsus 6.43.

${ }^{62}$ Martens 2012: 531-532, citing Commentary on the Song of Songs 2.8.4 and 2.8.6.

${ }^{63}$ Martens 2012: 537 n. 65, citing Against Celsus 4.39, 6.49 and 7.28-29. In the same note he cites On Prayer 23.3-4, where the premiss of an incorporeal paradise is attributed to his opponents without clear approbation or disapprobation.

${ }^{64}$ On which see Origen, First Principles 4.2.4

${ }^{65}$ Martens 2012: 537-538, citing Commentary on John 2.175-176 and 2.181-182.

${ }^{66}$ At Commentary on John 2.175ff the question whether John might be Elijah leads to the speculation that he was from heaven, paradise or some other world, and then to more doubtful hypothesis of his being an angel. Elijah, of course, would have entered paradise with a body.

${ }^{67}$ Martens 2019: 195, citing Homilies on Joshua 6.4, Homilies on Genesis 15.5 and Commentary on John 2.175-176. Martens 2019: 198, citing Homilies on 1Kings 28.9.10 and Commentaries on the Song 1.5 and 2.6; Martens 2019: 199, citing Homilies on Ezekiel 13 (where paradise is the place from which the angels fell). ${ }^{68}$ Martens 2019: 190-191.

${ }^{69}$ On Pamphilus, Jacob and John the Baptist (whom Martens accuses Edwards of overlooking) see Edwards 2002: 90, 98 101; 2008: 37-38; 2012: 319-321.
} 
should much be made of a comment in which Origen speaks of a paradise $i n$ the soul, for this is plainly not the paradise of souls that now concerns us. ${ }^{70}$ As Martens himself has shown at length, ${ }^{71}$ the historic sense of a narrative from the Old Testament is seldom annulled in Origen by either the psychic or the pneumatic sense.

It would therefore seem that no stronger evidence for the incorporeality of paradise in Origen can be adduced than the text which we have discussed above. If that does not prove what Origen's critics alleged - and it plainly did not disturb the orthodox compilers of the Philokalia, from which the Greek is taken - it offers no obstacle to our interpretation of First Principles 2.3.6 as another instance of his oft-repeated principle that no being can subsist without a body except for God.

\section{Who are Origen's interlocutors?}

We have seen then that the Platonism of Origen's day, which could not admit phantasia to the ideal realm - let alone to the mind of God, if it could entertain such a notion - could none the less posit an incorporeal hospital for the soul between embodiments, which restores to it the vision of the ideas and yet for us exists only in fantasy, since even a Plato can paint it only in sensuous imagery. I have argued that in opposing those who ascribed a similar character to the proper abode of the Saviour and the destination of saints, Origen is affirming a belief in the persistence of embodiment, even in paradise, which is certainly attested elsewhere in his writings. This thesis of course implies that his interlocutors were Christians, for there is no Platonic concept of a Saviour, and it was not his way, except in the work Against Celsus, to criticise a philosophic tenet which, in his view, had been noxious only to those outside the church. What professing Christians might he have known or known of, therefore, to whom this conceit of the Platonists had been a stumbling-block?

Martens and the scholars whom he opposes share the conviction that the elements in Origen that we call Platonic are not excrescent but integral to the defence of orthodoxy as he conceives it. Thus his principal aim in his speculations on the pre-existence of souls, as Martens says, is to lay the responsibility for our ills on our own free choices, and thus to acquit the Creator of the weakness and maleficence that are imputed to him by the Gnostics. ${ }^{72}$

\footnotetext{
${ }^{70}$ Martens 2019: 197, citing Homilies on Leviticus 16.4.1; Homilies on Numbers 12.3.4 and 26.4.1

${ }^{71}$ Martens 2012a: 64-66 etc.

${ }^{72}$ Martens 2015: 608-612. Cf. Ramelli 2013: 164-167.
} 
The title "Against the Gnostics", with the subtitle "Against those who say that the author of this world is evil", was attached by Porphyry to Enneads 2.9, the most acerbic treatise of Plotinus. He states that they were Christians, but heretics, who pretended to "set out from the ancient philosophy"; ${ }^{73}$ Plotinus addresses them as erstwhile friends, which appears to mean that they were once his fellow-pupils in Alexandria (Enneads 2.9.10). If that is so, it is not unlikely that Origen too had encountered a similar coupling of the rivers of the afterlife with the ideas:

Generally speaking, some of their tenets come from Plato, but others, which are new-minted to establish a philosophy of their own, are found to be alien to the truth. From Plato are their judgments, their rivers of Hades and their transmigrations. And when they make a plurality of the intelligibles being, intellect, the demiurge distinct from this, and the soul - this is taken from what is said in the Timaeus, for his words are: whatever ideas that dwell in the living existent are contemplated by intellect, that number the one who made this [world] designed that the whole should possess. (Enneads 2.9.6).

Among the texts used by the Gnostics Porphyry names a Zostrianus, against which Amelius write a refutation in forty books. It is generally agreed that the Coptic treatise of this title which was discovered at Nag Hammadi 1945 is a lacunose translation of the same book. ${ }^{74}$ At the beginning ${ }^{75}$ the seer recounts his emancipation from somatic darkness, psychic chaos and feminine desire (p. 1.10-12): his reward is to be instructed by the perfect child (2.10ff), who teaches him how division issues from the seat of the undivided, the aeon that truly exists (2.25ff). To ascend to this the soul must pass through a series of aeons, each of which has its own world of undying trees and imperishable fruit (48.12-16). In the course of instruction the seer learns that repentance and exile here are copies of the archetypal repentance and exile; he also learns that after successive baptisms in the waters of Beatitude, Vitality and Existence $^{76}$ he must pass through those of the Self-Begotten, the First-Appearing and the Hidden One, whereupon he will understand that these three waters are one (15.4-16; 22.712). The symbolism of the document thus includes four great waters, a revealer of salvation, and a combination of botanical imagery with an intimation that only the archetypal and invisible is real.

In the Book of Thomas the Contender, which may come from the same family of writings, ${ }^{77}$ the souls of the obdurate burn in Tartarus. (142.35) The studies of John Turner

\footnotetext{
73 See Igal 1981.

${ }^{74}$ See further Majercik 2005; Rasimus 2010.

75 The pagination is that of Nag Hammadi Codex VIII, as reproduced in Robinson 2000, vol. 4.

${ }^{76}$ See further Majercik 1992.

${ }^{77}$ Pagination of NHC Codex II, taken from Robinson 2000, vol. 2.
} 
have left no doubt that the Platonism of these 'Sethian' documents is not merely cosmetic, ${ }^{78}$ while their currency among Christians is attested by the early heresiologists. Origen will surely have been aware that in declaring them unorthodox he was also stemming a current of Greek thought, albeit one that was by no means representative of all Greeks.

\section{Conclusion}

If I have explained it correctly, the passage from the First Principles with which we began may be paraphrased as follows: 'we of the church do not believe that Christ belongs, or that souls depart, to a bodiless world of ideas, the existence of which is posited only by those who believe the imagery of the afterlife in both Plato and the scriptures to be phantastic rather than eikastic. We have also presented evidence that this is one of his typical animadversions on the abuse of allegory by both pagan and Gnostic teachers. It thus seems safe to conclude that he does not imagine the human soul after death to be wholly free of corporeality, at least not when it enters the preliminary abode that he calls the earthly paradise. ${ }^{79}$ It might he argued that he is speaking not of our intermediate but of our ultimate destination, since he also rejects the notion that the Saviour comes from this incorporeal world. In Gnostic thought, however, the emissaries of the highest God may descend from any of the spheres that house his reified attributes, and I therefore do not think that the present study can yield a conclusive answer to questions regarding the final state of the soul in Origen's eschatology. ${ }^{80}$ Nor can it determine whether all souls were incorporeal in the beginning, unless we assume that paradise is either that primordial state or an allegory of it.

Am I denying that Origen was a Platonist? If anything is apparent from my discussion, it is that belief in some form of corporeality after death is no less Platonic - and perhaps, by weight of numbers, more Platonic ${ }^{81}$ - than belief in absolute incorporeality. Whatever may be un-Platonic or anti-Platonic in Origen must be sought, if anywhere, at a level too deep to be explored in the present study. If the mere appropriation of tenets or motifs from Plato suffices to make one a Platonist, we could hardly refuse this appellation to Origen; if, on other hand, we mean by a Platonist one who, in any competition between authorities, will affirm the superiority of Plato, ${ }^{82}$ it is obvious that to call Origen a Platonist would conceal more than it

\footnotetext{
${ }^{78}$ See Turner 2001, esp. 720-744 on the Gnostics of Plotinus.

${ }^{79}$ On its penultimate status see First Principles 2.11.6.

${ }^{80}$ For the view that he "secretly" postulates a final state of incorporeality see Scott 2015: 122. Contrast Ramelli 2013: 181-183 etc.

${ }^{81}$ See Alt 1993 for doubts as to whether even Plotinus envisaged a permanent escape from the bodily condition.

82 Ramelli 2009: 217-263 musters numerous authorities in support of her conception of a Christian Platonism (even if not so called by its proponents) which entailed a Christianization of Hellenism rather than a
} 
explains. Those who assert and those who eschew the term "Platonist" today are at least of one mind in rejecting the view that Origen was at bottom not a Christian but a pagan; all agree that his use of philosophy was purposeful and elective, so that the question before him was never 'How can I, as a Platonist, come to terms with the crudity and absurdity of Christian thought?', but rather 'When can Plato help me, as a Christian, to prove to the philosopher, the heretic and the neophyte that nothing in our religion is either crude or absurd?'

Hellenization of Christianity. Ramelli 2017: 16-17 rightly points out that Numenius, Iamblichus and Proclus do not quite take Plato as their sole authority; yet it still seems clear that all these writers treat Plato with a reverence which Christians extended only their own scriptures. 


\section{Bibliography: primary sources}

Alcinous, Enseignement des Doctrines de Platon, ed. J. Whittaker (Paris: Belles Lettres 1990).

Atticus, Fragments, ed. E. des Places (Paris: Belles Lettres 1997).

Damascius [Olympioodorus], In Platonis Phaedonem Commentaria, ed. W. Norvin (Leizig: Teubner 1913.

Eusebius, Praeparatio Evangelica, ed. K. Mras (Berlin: De Gruyter 19922).

Iamblichus, De Communi Scientia Mathematica, ed. N. Festa (Leipzig: Teubner 1891).

Numenius, Fragments, ed. E. des Places (Paris: Belles Lettres 1973).

Olympiodorus, in Platonis Gorgiam Commentaria, ed. L. G. Westerink (Berlin: De Gruyter 1970).

Origen, Homilien zu Genesis, Exodus, Leviticus, ed. W. Baehrens (Leipzig: Hinrichs 1920).

Origen, Homilien zu 1 Samuel, zum Hohenlied und zu den Propheten, ed. W. Baeherns (Leipzig: Hinrichs 1925).

Origen, Die Kommentierung des Buches Genesis, ed. K. Metzler (Berlin: De Gruyter 2010).

Origen, Jeremiashomiilien, ed. E. Klostermann (Leipzig: Hinrichs 1901).

Origen, Philocalie 1-20, ed. M. Harl (Paris: Cerf 1983).

Origen: De Principiis, ed. P. Koetschau (Leipzig: Hinrichs 1913).

Origen, Die Schrift vom Martyrium, Gegen Celsus, die Schrift vom Gebet, ed. P. Koetschau (Leipzig: Hinrichs 1899).

Plotinus, Opera, ed. P. Henry and H.-R. Schwyzer, 3 vols (Oxford: Clarendon Press 1964). Includes Porphyry's Life of Plotinus.

Plutarch, Tutti I Moralia, ed. E. Lelli and G. Pisani (Milan: Bompianai 2017).

Porphyry, Opuscula, ed. A. Nauck (Leipzig: Hinrichs 1886).

Proclus, De Decem Dubitiationibus supra Providentiam, in Tria Opuscula, ed. A. Bellanti (Milan: Bompiani 2004).

Proclus, in Platonis Timaeum Commentaria, ed. E. Diehl, 3 vols (Leipzig Teubner 19031905).

Proclus, In Rem Publicam Commentaria, ed. W. Kroll (Leipzig: Teubner 1899-1901).

Syrianus, In Aristotelis Metaphysica Commentaria, ed. W. Kroll (Berlin: Reimer 1902). 


\section{Bibliography: scholarly literature}

Alt, K. (1993), Weltflucht und Weltbejahung: zur Frage des Dualismus bei Plutarch, Numenius, Plotin (Stuttgart: Akademie der Wissenschaften 1993).

Alviar, J. (1993), Klesis: The Theology of the Christian Vocation according to Origen (Blackrock: Four Courts Press 1993).

Armstrong, A. H. (1960), "The Origin of the Doctrine that 'The Intelligibles are not outside the Intellect", Entretiens Hardt V: Les Sources de Plotin ((Vandoeuvres: Geneva: Fondation Hardt 1960), 391-413.

Bammel, C. P. (1989), “Adam in Origen”, in R. D. Williams (ed.), The Making of Orthodoxy: Essays in Honour of Henry Chadwick (Cambridge: Cambridge University Press), 62-93.

Behr, J., ed. (2017), Origen: On First Principles, vol. 1 (Oxford: Oxford University Press).

Bendinelli, L. (1997), Il commentario a Matteo di Origene. L' ambito della metodologica scholastica nell' antichità (Rome: Instituto Pontifico Augustinianum).

Blosser, B. (2012), Become like the Angels: Origen's Doctrine of the Soul (Washington D.C.: Catholic University of America Press).

Boys-Stones, G. (2012), "Harpocration of Athens: Etymology and Metaphysics in the Platonist Revival", Journal of Hellenic Studies 132, 1-6

Briggman (2019), God and Christ in Irenaeus (Oxford: Oxford University Press).

Clark, E.A. (1992). The Origenist Controversy (Princeton: Princeton University Press).

Crouzel, H. (1961), Origène: et la connaissance mystique (Paris).

Crouzel, H. and M. Simonetti, eds (1978), Origène: Traité de Principes, vol. 2 (Paris: Cerf),

Dillon, J. M. (1996), The Middle Platonists (Ithaca, NY: Cornell University Press.

Dillon, J. M. (2011), “The Ideas as Thoughts of God”, Études Platoniciennes 8, 31-42.

Dodds, E. R. (1963), Proclus: Elements of Theology (Oxford: Clarendon Press 1963).

Dorival, G. (1992), "L'apport d'Origène pour la connaissance de la philosophie grecque”, in R. Daly (ed.), Origeniana Quinta (Leuven: Peeters), 189-216.

Edwards, M. J. (2002), Origen against Plato (Farnham: Ashgate 2002).

Edwards, M. J. (2008), “Origen's Platonism: Questions and Caveats”, Zeitschrift für Antikes und Christentum 12 (2008), 20-38. 
Edwards, M. J. (2012), "Further Reflections on the Platonism of Origen", Adamantius 18, 317-324.

Edwards, M. J. (2019), “Origen in Paradise: A Response to Peter Martens”, Zeitschrift für Antikes und Christentum 23 (2019), 163-185.

Fernandez, S., ed. (2015), Orígenes: Sobre los Principios (Madrid: Ciudad Nueva).

Finamore, J. (1985), Iamblichus and the Theory of the Vehicle of the Soul (Chico: American Philological Association).

Harl, M. "La préexistence des âmes dans l'oeuvre d'Origène”, in L. Lies (ed.), Origeniana Quarta (Innsbruck: Tyrolia), 238-258.

Heine, R.E (1995), "The introduction to Origen's Commentary on John compared with the Introductions to the Ancient Philosophical Commentaries on Aristotle", in G. Dorival and A. Le Boulluec (eds), Origeniana Sexta (Peeters, Leuven), 3-12.

Hadot, I. (1987), "Les introductions aux commentaires exégétiques chez les auteurs néoplatoniciens et les auteurs chrétiens", in: M. Tardieu (ed.), Les règles de l'interprétation (Paris: Cerf 1987), 99-122.

Heine, R. (2010), Origen: Homilies on Genesis and Exodus (Washington: Catholic University of America).

Humphries, T. (2017), Who is Chosen? Four Theories about Salvation (Eugene, Oregon: Wipf and Stock).

Igal, J. (1981), "The Gnostic and the 'Ancient Philosophy", in H. J. Blumenthal and R. A. Markus (eds), Neoplatonism and Early Christian Thought (London: Variorum), 138-149.

Kelly, J.N.D (2000), Early Christian Doctrines (London: Continuum).

Lamberton, R. (1986), Homer the Theologian: Neoplatonic Allegorical Reading and the Growth of the Epic Tradition (Berkeley: University of California Press).

Lampert, J. (1996), “Origen on Time”, Laval Théologique et Philosophique 52 (1996), 649664.

Lauro, E. Dively (2004), "Fall, The" in J. McGuckin (ed.), The Westminster Handbook to Origen (Westminster John Knox Press), 100-101.

Lear, T. J. (1989), "Rhetoric and the Theory of Forms in Plato's 'Phaedrus", Acta Classica $32,19-27$.

Limone, V. (2018), Origene e la filosofia greca (Brescia: Morcelliana).

Majercik, R. (1992), “The Being-Life-Mind Triad in Gnosticism and Neoplatonism”, Classical Quarterly 42, 475-488. 
Majercik, R. (2005), “Porphyry and Gnosticism”, Classical Quarterly 55, 277-292.

Martens, P. W. (2012), “Origen's Doctrine of Pre-Existence and the Opening Chapters of Genesis", Zeitschrift für Antikes Christentum 16, 516-549.

Martens, P. W. (2012a): Origen and Scripture: the Contours of the Exegetic Life (Oxford: oxford University Press).

Martens, P. W. (2014), “A Fitting Portrait of God: Origen's Interpretation of the 'Garments of Skins",, in C. V. Stichele and S. Scholz (eds), Hidden Truths from Eden: Esoteric Readings of Genesis 1-3 (Atlanta: Society of Biblical Literature 2-14), 55-84.

Martens, P. W. (2015), "Embodiment, Heresy and the Hellenization of Christianity", Journal of Early Christian Studies 108, 594-620.

Martens, P. W. (2019), "Response to Edwards", Zeitschift für Antikes Christentum 23, 186200 .

Moreschini, C. (1987), "Attico", in W. Haase and H. Temporini (eds), Aufstieg und Niedergang der römischen Welt II.36.2 (Berlin: De Gruyter), 477-491.

O'Brien, C. S. (2015), The Demiurge in Ancient Thought (Cambridge: Cambridge University Press).

O’Brien, D. (1992), "Plotin et le voeu du silence", in L. Brisson, M. O. Goulet-Cazé, R. Goulet and D. O’Brien (eds), Porphyre. La Vie de Plotin, vol. 2 (Paris: Vrin), 419-459.

Pârvan, A. (2012), "Genesis 1-3: Augustine and Origen on the 'Coats of Skin"”, Vigiliae Christianae 66), 56-92.

Ramelli, I. (2009), "Origen, Philosophy and Christian Platonism: Re-thinking the Christianization of Hellenism”, Vigiliae Christianae 63 (2009), 217-263.

Ramelli, I. (2013), The Christian Doctrine of Apokatastasis: A Critical Assessment from the New Testament to Eriugena (Leiden: Brill).

Ramelli, I. (2014), “Alexander of Aphrodisias: A Source of Origen's Philosophy?”, Philosophie Antique 14, 237-289.

Ramelli, I. (2017), “Origen and the Platonic Tradition”, Religions 8.2, 1-25 (on-line).

Ramelli, I. (2018), “Origen”, in A. Marmodoro and S. Cartwright (eds), A History of Mind and Body in Late Antiquity (Cambridge: Cambridge University Press), 245-266.

Rankin, D. (2017), The Early Church and the Afterlife: Post-Death Existence in Athenagoras, Tertullian, Origen and the Letter to Rheginos (London: Routledge).

Rasimus, T. (2010), "Porphyry and the Gnostics: Reassessing Pierre Hadot's Thesis in Light of the Second- and Third- Century Sethian Treatises", in J. D. Turner and K. Corrigan (eds), Plato's Parmenides and its Heritage, vol. 1 (Atlanta: Society of Biblical Literature 2010), 81111. 
Robinson, J. M., ed. (2000), Coptic Gnostic Library, 5 vols (Leiden: Brill).

Rombs, R. (2007), “A Note on the Status of Origen's De Principiis in English”, Vigiliae Christianae 61, 21-29.

Schibli, H. (1993), "Hierocles of Alexandria on the vehicle of the Soul", Hermes 121, 109117.

Scott, M. (2015), Journey Back to God: Origen on the Problem of Evil (Oxford: Oxford University Press).

Simonetti, M. (1962), “Alcune osservazioni sull' interpretazione origeniana di 'Genesi' 2.7 e 3.21”, Aevum 36, 370-381.

Stead, G. C. (1964), “The Platonism of Arius”, Journal of Theological Studies 15, 16-31.

Tarrant, H. (2015), "The Phaedo in Numenian Allegorical Interpretation”, in S.

Descommines, P. d'Hoine and M.-A. Gavray (eds.), Ancient Readings of Plato's Phaedo, 134-153.

Tolan, D. (2019), "The Impact of the Opuoov́бıv on the Divine Ideas", in P. G. Paulos, L. F. Janby, E. Emilsson and T. Tollefsen (eds), Platonism and Christian Thought in Late Antiquity (London: Routledge), 129-150.

Turner, J. D. (2001), Sethian Gnosticism and the Platonic Tradition (Paris: Peeters).

Tzamalikos, P. (2006), Origen: Cosmology and Philosophy of Time (Leiden: Brill).

Whittaker, J. (1987), "Platonic Philosophy in the early Centuries of the Empire", in W. Haase and H. Temporini (eds), Aufstieg und Niedergang der römischen Welt II.36.1 (Berlin: De Gruyter 1), 81-123.

Wolfson. H. A. (1956), The Philosophy of the Church Fathers (Cambridge, Mass.: Harvard University Press). 
